\title{
Interaction of Pratylenchus zeae with Four Soil Fungi on Sorghum ${ }^{1,2}$
}

\author{
Domingo Bee-Rodríguez and Alejandro Ayala ${ }^{3}$
}

\begin{abstract}
In a greenhouse experiment, a population consisting of 1,500 Pratylenchus zeae in $20-\mathrm{cm}$ pots were pathogenic on sorghum, and suppressed top and root growth. Pronounced necrosis of the roots resulted. Top growth was retarded by combinations of $P$. zeae-Curvularia spp., $P$. zeae-Fusarium moniliforme, $P$. zeae-Rhizoctonia solani, and $P$. zeae-Macrophomina sp., and by $F$. moniliforme and $R$, solani, alone. All nematode-fungi combinations and all fungi alone suppressed root growth. The combination $P$. zeaeCurvularia spp. produced most damage. $P$. zeae- $R$. solani, Curvularia spp., and $F$. moniliforme produced severe necrosis of sorghum roots. An initial inoculum of $750 \mathrm{P}$. zeae in $20 \mathrm{~cm}$ pots was not pathogenic on sorghum in a second experiment. Only the combination of $P$. zeae-F. moniliforme affected the fresh root weights; dry root weights were retarded significantly by $P$. zeae- $F$. moniliforme and by $F$. moniliforme, alone. The intensity of necrosis also varied with the different inocula.
\end{abstract}

\section{INTRODUCTION}

Sorghum [Sorghum bicolor (L.) Moench] is affected by a number of diseases $(5,7,11)$, pests, aluminum toxicity, and low soil $\mathrm{pH}$. Several nematode species, especially Pratylenchus zeae, are associated with a purplish color of the foliage 2 or 3 weeks after germination, wilting, and rapid death of the plants that resembles a die-back, few roots, which turn reddish, and a root cortex that peels easily. This condition is especially evident in clay soils of the Coto (Oxisol) series. Several soil fungi (Macrophomina sp., Fusarium moniliforme, Curvularia spp. and Rhizoctonia solani) were also isolated from root cultures.

Pathogenicity of Pratylenchus sp. has been demonstrated on several agricultural crops $(2,3,4,6)$. Endo (4) demonstrated that $P$. zeae reproduced readily on corn and sorghum roots.

Pammel et al. (11) observed that Fusarium caused a root rot on corn which is expressed as a reddish color. These plants could be easily pulled from the soil. This pathogen also attacked sorghum; the main symptom was stem breaking at the first node, but the roots were not severely injured. Leukel and Martin (7) demonstrated the pathogenicity of $F$. moniliforme on sorghum; the incidence of the disease was greater at higher temperatures, which was corroborated by Johnson et al. (5).

'Manuscript submitted to Editorial Board March 29, 1977.

2 Part of a thesis submitted to the Graduate School in partial fulfilment of the requirements for the Master of Science in Agriculture. Part of this research was sponsored by AID Grant No. C-1087.

${ }^{3}$ Graduate Student, Department of Agronomy, Faculty of Agriculture, and Nematologist, Agricultural Experiment Station, Mayagüez Campus, University of Puerto Rico, Río Piedras, P.R. 
The effects of interactions between nematodes and fungi are well known on several crops. Norton (9) reported an association of Pratylenchus hexincisus with charcoal rot of sorghum. Fungi, especially Fusarium sp. $(1,5,7,12)$ and Curvularia sp. (1), have been isolated from sorghum seeds.

The objectives of these experiments were to determine the effect of $P$. zeae, alone or in combination with four soil fungi on sorghum.

\section{MATERIALS AND METHODS}

Fusarium moniliforme, Macrophomina spp., Curvularia spp., and $R$. solani were isolated from the roots of sorghum obtained from the experimental farm of the Mayagüez Institute of Tropical Agriculture (MITA) at Isabela. They were cultured in PDA (potato dextrose agar) and, after 10 days of growth, used to inoculate the test plants.

To apply the fungi, the content of a petri dish was blended with 150 $\mathrm{cm}^{3}$ of water for $10 \mathrm{~s}$ and the suspension added to the soil surface around the plant. The nematode inoculum was extracted from roots of sorghum plants in a mist chamber. The nematodes present in a suspension were calculated, and a predetermined number pipetted into holes in the soil around each plant.

Eight sorghum (T.E. Haygrazer) seeds were planted per $20-\mathrm{cm}$ clay pot, containing equal parts of top soil, filter-press cake, and river sand, and later thinned to two plants. The treatments used were: 1,500 P. zeae; Macrophomina sp.; Curvularia spp.; $R$. solani; F. moniliforme; 1,500 P. zeae and Macrophomina sp.; 1,500 P. zeae and Curvularia spp.; 1,500 P. zeae $+R$. solani; 1,500 P. zeae and $F$. moniliforme; and the controls (free of microorganisms).

The pots were placed on a greenhouse bench in a complete randomized block design, replicated 5 times. Pots were separated and protected to minimize contamination during watering. Ambient temperature during the 5 -week experiment was $24-36^{\circ} \mathrm{C}$. The following parameters were evaluated at the end of the experiment: stem fresh and oven-dry weights, plant height, and disease index (0-5 scale). Fungi were reisolated and the nematode populations assessed in $100 \mathrm{~cm}^{3}$ of soil and $10 \mathrm{~g}$ of roots.

In a second experiment, the effects of the two fungi causing more damage in the first trial, (Curvularia spp. and $F$. moniliforme), and $P$. zeae were studied in different combinations. The treatments used were: 750 P. zeae; Curvularia spp.; F. moniliforme; 750 P. zeae and Curvularia spp.; 750 P. zeae and F. moniliforme; Curvularia spp. and $F$. moniliforme; 750 P. zeae, Curvularia spp. and F. moniliforme; and the control.

The soil was a Coto clay (Oxisol) brought from the MITA farm at 
Isabela and partially sterilized with methyl bromide at the rate of 454 $\mathrm{g} / 334.64 \mathrm{~m}^{2}$. Four seeds were planted per pot and later thinned to one.

The procedures described for the first experiment were employed for growing fungal and nematode inocula. The statistical design, number of replicates, and all other cultural procedures were similar to those employed in the first experiment.

\section{RESULTS}

The interaction of $P$. zeae with four soil fungi are shown in table 1. Top weight was suppressed $(\mathrm{P}=.05)$ by the combination $P$. zeaeCurvularia spp., by $F$. moniliforme, and by $P$. zeae. The top dry weight of plants inoculated with $P$. zeae-Curvularia spp. was signifi-

TABLE 1. - Growth and root necrosis of sorghum plants inoculated with Pratylenchus zeae alone and in combinations with four soil fungi

\begin{tabular}{|c|c|c|c|c|}
\hline \multirow[b]{2}{*}{ Treatments } & \multirow{2}{*}{$\begin{array}{l}\text { Tops dry } \\
\text { weights }\end{array}$} & \multicolumn{2}{|c|}{ Root } & \multirow{2}{*}{$\begin{array}{c}\text { Necrosis } \\
\text { index }^{1}\end{array}$} \\
\hline & & $\begin{array}{c}\text { Fresh } \\
\text { weights }\end{array}$ & $\begin{array}{c}\text { Dry } \\
\text { weights }\end{array}$ & \\
\hline & $G$ & $G$ & $G$ & \\
\hline P. zeae-Curvularia spp. & $25.1 \mathrm{c}^{2}$ & $30.50 \mathrm{~d}$ & $2.6 \mathrm{a}$ & $0.8 \mathrm{~d}$ \\
\hline$P$. zeae-F. moniliforme & $27.4 \mathrm{abc}$ & $32.25 \mathrm{~cd}$ & $3.1 \mathrm{a}$ & $1.2 \mathrm{bcd}$ \\
\hline P. zeae-R. solani & $27.5 \mathrm{abc}$ & $33.85 \mathrm{~cd}$ & $3.2 \mathrm{a}$ & $2.2 \mathrm{abc}$ \\
\hline P. zeae-Macrophomina sp. & $26.9 \mathrm{abc}$ & $35.60 \mathrm{bcd}$ & $3.3 \mathrm{a}$ & $1.0 \mathrm{bcd}$ \\
\hline F. moniliforme & $26.4 \mathrm{bc}$ & $35.65 \mathrm{bcd}$ & $3.1 \mathrm{a}$ & $1.8 \mathrm{abc}$ \\
\hline R. solani & $27.8 a b c$ & $37.80 \mathrm{bcd}$ & $3.0 \mathrm{a}$ & $1.6 \mathrm{bc}$ \\
\hline P. zeae & $26.4 \mathrm{bc}$ & $39.20 \mathrm{abcd}$ & $3.9 \mathrm{a}$ & $3.2 \mathrm{a}$ \\
\hline Macrophomina sp. & $28.1 \mathrm{abc}$ & $42.35 \mathrm{abc}$ & $3.8 \mathrm{a}$ & $1.6 \mathrm{bc}$ \\
\hline Curvularia spp. & $28.9 \mathrm{ab}$ & $45.65 \mathrm{ab}$ & $3.7 \mathrm{a}$ & $2.4 \mathrm{ab}$ \\
\hline Control & $29.7 \mathrm{a}$ & $49.25 \mathrm{a}$ & $6.0 \mathrm{~b}$ & $0 \mathrm{~d}$ \\
\hline
\end{tabular}

${ }^{1}$ Index of necrosis based on classification of 0 (no necrosis) to 5 (extensive necrosis).

${ }^{2}$ Means with one or more letters in common do not differ significantly at $\mathrm{P}=.05$ according to Duncan's Multiple Range Test.

cantly lower $(\mathrm{P}=, 05)$ than that of plants inoculated with Curvularia spp. alone. The mean fresh root weight of the control plants was greater $(\mathrm{P}=.05)$ than that of plants infected with the combinations $P$. zeae-Curvularia spp., $P$. zeae-F. moniliforme, $P$. zeae- $R$. solani, $P$. zeae-Macrophomina sp., $F$. moniliforme, and $R$. solani. The adverse effect of the combination $P$. zeae-Curvularia spp. on plant roots was greater than the effects of Curvularia spp., and of Macrophomina sp. All treatments $(\mathrm{P}=.05)$ retarded root growth. Although not significantly different from the others, the plants infected with the combination $P$. zeae-Curvularia spp. appeared to be more severely damaged. Pratylenchus zeae produced more necrosis, although not significantly different from Curvularia spp., F. moniliforme, and P. zeae-R. solani. 
The first two produced more necrosis alone than when inoculated together.

The population levels of $P$. zeae were much higher in the roots than in the soil. There was no apparent effect of competition from the different fungi on the reproduction of the lesion nematode as demonstrated by final populations.

Results obtained from a second experiment to evaluate the effect of $P$. zeae alone and in combination with Curvularia spp. and $F$. moniliforme are illustrated in table 2. Plant height was not adversely affected by nematodes or fungi alone or by combinations of them. Top fresh weights with $F$. moniliforme-infected plants was greater than those of the control and $P$. zeae, but top dry weight was similar in all treatments. Only the combination $P$. zeae-F. moniliforme suppressed root growth.

TABLE 2. - Growth and necrosis of sorghum plants inoculated with Pratylenchus zeae, Fusarium moniliforme, and Curvularia spp. alone and in different combinations

\begin{tabular}{|c|c|c|c|c|c|}
\hline \multirow[b]{2}{*}{ Treatments } & \multirow[b]{2}{*}{ Height } & \multirow{2}{*}{$\begin{array}{l}\text { Root fresh } \\
\text { weight }\end{array}$} & \multicolumn{2}{|c|}{ Top } & \multirow{2}{*}{$\begin{array}{l}\text { Necrosis } \\
\text { index }^{1}\end{array}$} \\
\hline & & & $\begin{array}{c}\text { Fresh } \\
\text { weight }\end{array}$ & $\begin{array}{c}\text { Dry } \\
\text { weight }\end{array}$ & \\
\hline & $\mathrm{Cm}$ & $G$ & $G$ & $G$ & \\
\hline P. zeae & $24.26 b^{2}$ & $22.40 \mathrm{~b}$ & $4.32 \mathrm{abc}$ & $0.84 a b$ & $2.2 \mathrm{abc}$ \\
\hline P. zeae-F. moniliforme & $26.98 \mathrm{~b}$ & $27.96 \mathrm{ab}$ & $3.90 \mathrm{c}$ & $.53 \mathrm{~b}$ & $2.6 \mathrm{abc}$ \\
\hline P. zeae-Curvularia sp. & $24.60 \mathrm{~b}$ & $24.46 \mathrm{ab}$ & $4.64 \mathrm{bc}$ & $.86 \mathrm{ab}$ & $2.4 \mathrm{abc}$ \\
\hline $\begin{array}{l}\text { P. zeae-Curvularia sp.-F. mo- } \\
\text { niliforme }\end{array}$ & $27.24 \mathrm{~b}$ & $25.68 \mathrm{ab}$ & $6.92 \mathrm{ab}$ & $1.04 \mathrm{ab}$ & $3.4 \mathrm{a}$ \\
\hline F. moniliforme & $32.38 \mathrm{a}$ & $33.92 \mathrm{a}$ & $5.72 \mathrm{bc}$ & $.55 \mathrm{~b}$ & $1.6 \mathrm{bc}$ \\
\hline Curvularia sp. & $26.02 \mathrm{~b}$ & $23.54 \mathrm{ab}$ & $5.10 \mathrm{bc}$ & $.78 a b$ & $1.8 \mathrm{abc}$ \\
\hline Curvularia sp. F. moniliforme & $28.44 \mathrm{ab}$ & $30.74 \mathrm{ab}$ & $8.76 \mathrm{a}$ & $1.09 \mathrm{ab}$ & $3.0 \mathrm{ab}$ \\
\hline Control & $28.20 \mathrm{ab}$ & $21.52 \mathrm{~b}$ & $7.02 \mathrm{ab}$ & $1.46 \mathrm{a}$ & $1.0 \mathrm{c}$ \\
\hline
\end{tabular}

' Index of necrosis based on classification of 0 (no necrosis) to 5 (intensive necrosis).

${ }^{2}$ Means followed by one or more letters in common do not differ significantly at $\mathrm{P}=$ .05 according to Duncan's Multiple Range Test.

Both $F$. moniliforme alone and combined with $P$. zeae significantly reduced dry root (table 2 ). The combinations $P$. zeae- $F$. moniliformeCurvularia spp.; and $F$. moniliforme-Curvularia spp. caused significantly more necrosis on sorghum roots than on the controls. There were no significant differences among the other treatments. Some necrosis developed also on the roots of control plants, which indicated the presence of a contaminant.

Final population levels of $P$. zeae were higher from the roots than in the soil samples.

\section{DISCUSSION}

Under the conditions of the first experiment, $P$. zeae and the fungi Curvularia spp., $F$. moniliforme, Macrophomina sp., or $R$. solani 
alone and in combinations suppressed sorghum root growth. Top dry weights were affected by $P$. zeae, $P$. zeae-Curvularia spp., and by $F$. moniliforme; $P$. zeae, $F$. moniliforme, Curvularia spp. and $P$. zeae-R. solani caused more necrosis on the plant roots. These results suggest that the lesion nematode and the four fungi are pathogenic on sorghum. However, the symptoms observed in the field were not produced in the greenhouse. Furthermore, results are different from those obtained by Norton (9) with $P$. hexincisus and Macrophomina phaseoli in the sorghum cultivar Combine 7078. The nematodes and the plant variety used and factors such as high soil temperature $\left(24-36^{\circ} \mathrm{C}\right)$ and humidity were different. Norton (9) reported that the damage produced by both pathogens increased under conditions of low humidity.

Stanley B. King ${ }^{4}$ observed a sorghum disease in Nigeria similar to that described here. He isolated the four fungi genera used in our experiments but was unable to reproduce the disease under greenhouse conditions. He attributes this failure to sorghum plants never being exposed to conditions of stress. Johnson et al. (5) demonstrated that $F$. moniliforme infection and pathogenicity of sorghum roots are affected by temperature.

Some of the combinations in our experiments indicated antagonism: Pratylenchus zeae alone caused necrosis, but not when combined with $F$. moniliforme or Macrophomina sp. However, this apparent antagonism did not affect the reproductive potential of $P$. zeae. Litrell and Johnson (8) obtained similar results with Pythium aphanidermatum and Belonolaimus longicaudatus.

The general growth and development of the sorghum plants in a second experiment, using the same variety, was poor compared to those of the first experiment. The difference may have been due to the change in growth media used. Fusarium moniliforme alone or in combination with $P$. zeae retarded root growth by 63 and $64 \%$, respectively. This response suggests that, under the prevailing conditions, only $F$. moniliforme was pathogenic to sorghum roots. Inhibition of root development by $P$. zeae was not significant, suggesting that the inoculum used (750 specimens/plant) was below the critical level; 1,500 had been used in the first trial.

Temperature $\left(26-38^{\circ} \mathrm{C}\right)$ may also have exerted its effect on nematode reproduction and pathogenic capacity. Palmer et al. (10) found that at $24^{\circ} \mathrm{C}$, dry weight of corn roots was $12 \%$ lower in $\mathrm{F}$. moniliformeinfected plants, $30 \%$ in plants infected with the fungus and $P$. scribneri, and $39 \%$ when the nematode was alone.

\section{RESUMEN}

En un experimento de invernadero, 1,500 nematodos de la especie Pratylenchus zeae por tiesto de $20 \mathrm{~cm}$. fueron patogénicos en sorgo, reduciendo el crecimiento del follaje y

${ }^{4}$ Personal communication. 
de las raices. Se observó, además, necrosis marcada de las raices. El crecimiento foliar fue adversamente afectado por las siguientes combinaciones de nematodos y hongos: $P$. zeae-Curvularia spp., $P$. zeae-Fusarium moniliforme, $P$. zeae-Rhizoctonia solani, y $P$. zeae-Macrophomina sp., y por hongos solos: $F$. moniliforme y $R$. solani. Todas las combinaciones nematodos-hongos y todos los hongos solos inhibieron el desarrollo radical. La combinación $P$. zeae-Curvularia spp. causó más daño. $P$. zeae, $P$. zeae- $R$. solani, Curvularia spp. y $F$. moniliforme indujeron la formación de una necrosis severa. El inóculo inicial de $750 \mathrm{P}$. zeae por tiesto de $20 \mathrm{~cm}$. no fue patogénico al sorgo. Solamente la combinación $P$. zeae- $F$. moniliforme disminuyó el peso fresco de las raíces; el peso seco fue afectado por $P$. zeae- $F$. moniliforme y por $F$. moniliforme solo. La intensidad necrótica también varió con el inóculo.

\section{LITERATURE CITED}

1. Bain, D. C., Fungi recovered from seed of Sorghum vulgare Pers. Phytopathology 40: 521-2, 1950.

2. Bergeson, G. B., A report on the testing of onion varieties for resistance to lesion nematodes, Plant Dis. Rep. 46: 535-6, 1962.

3. Dickerson, O. J., Darling, H. M., and Griffin, G. O., Pathogenicity and population trends of Pratylenchus penetrans on potato and corn. Phytopathology 54: 317-22, 1964

4. Endo, B. Y., Responses of root-lesion nematodes, Pratylenchus brachyurus and $P$. zeae, to various plant and soil types. Phytopathology 49: 417-21, 1959.

5. Johnson, D. L., Davison, A. D., and Heathman, E. S., A Fusarium root rot of Sorghum vulgare. Phytopathology 56: 148-9 (Abstr.), 1966.

6. Koike, H., and Román, J., Pathogenicity of Pratylenchus brachyurus and Pythium graminicola to sugarcane. Phytopathology 60: 1562-5, 1970.

7. Leukel, R. W., and Martin, J. A., Seed rot and seedling blight of sorghum. USDA Tech. Bull 839: 1-26, 1943.

8. Litrell, R. W., and Johnson, A. W., Pathogenicity of Pythium aphanidermatum to Chrysanthemum in combined inoculations with Belonolaimus longicaudatus or Meloidogyne incognita. Phytopathology 59: 115-6, (Abstr.) 1969.

9. Norton, D. C., The association of Pratylenchus hexincisus with charcoal rot of sorghum. Phytopathology 48: 355-8, 1958.

10. Palmer, L. T., McDonald, D., and Kommedahl, T., The ecological relationship of Fusarium moniliforme to Pratylenchus scribneri in seedling blight of corn. Phytopathology 57: 825 (Abstr.), 1967.

11. Pammel, L. H., King, C. M., and Seal, J. L., Studies on a Fusarium disease of corn and sorghum (Preliminary). Iowa State Col. Res. Bull. 33: 113-36, 1916.

12. Swarup, G., Hansing, E. D., and Rogerson, C. T., Fungi associated with sorghum seed in Kansas. Phytopathology 46: 28 (Abstr.), 1956. 